\title{
Analisis Perhitungan Beban Pendinginan Ruang Dhammasala Vihara Padumuttara menggunakan Metode CLTD
}

\author{
Ananda Karuna Jaya ${ }^{1}$, Caesar Ondolan Harahap ${ }^{2}$, Rahmi Andarini ${ }^{3}$ \\ Fakultas Teknik dan Informatika, Universitas Multimedia Nusantara, Tangerang, Indonesia \\ 1ananda.jaya@student.umn.ac.id, ${ }^{2}$ caesar.harahap@umn.ac.id, ${ }^{3}$ rahmi.andarini@lecturer.umn.ac.id
}

Diterima 19 Juli 2020

Disetujui 10 Oktober 2020

\begin{abstract}
Dhammasala room of Padumuttara Temple has an indoor temperature of $28,56^{\circ} \mathrm{C}$ and relative humidity of 80,6\%. According to SNI 03-6572-2001 and a previous literature study, this temperature is outside the thermal comfort zone for tropical climate. Aiming to improve thermal comfort of Dhammasala room with an HVAC system efficiently, the cooling load of the room is analyzed using the Cooling Load Temperature Difference (CLTD) method. The results are also compared with results from other cooling load calculation sofware. The recommended HVAC System for Dhammasala room of Padumuttara Temple is a chiller with a capacity of 30-40TR.
\end{abstract}

Keywords: Cooling Load, CLTD, Dhammasala, Thermal Comfort, HVAC System.

\section{PENDAHULUAN}

Konsumsi energi pada sektor bangunan lebih tinggi dibandingkan dengan sektor lainnya. Walaupun persentasenya beragam di setiap negara, bangunan berkontribusi terhadap 30-40\% dari kebutuhan energi global [1] . Hal ini disebabkan terutama oleh penggunaan sistem Heating Ventilation and Air Conditioning (HVAC) untuk mencapai kenyaman termal pada sektor tersebut. Kenyamanan termal khususnya di daerah tropis seperti yang ditunjukkan pada psychrometric chart pada Gambar 1 berada pada $24-30^{\circ} \mathrm{C}$ dengan kelembaban relatif $80-65 \%$ [2]. Untuk meningkatkan efisiensi energi sebuah bangunan, penggunaan sistem HVAC yang kapasitasnya sesuai dengan beban pendinginan (cooling load) bangunan tersebut sangat penting. Peningkatan suhu pada lingkungan sebagai akibat perubahan iklim dapat mempengaruhi suhu pada bangunan. Ruangan yang akan dihitung beban pendinginannya pada penelitian ini adalah ruang Dhammasala Vihara Padumuttara yang berlokasi di Jl. Bakti No.14, RT/RW 001/004, Sukasari, Kec. Tangerang, Kota Tangerang. Secara koordinat geografis, lokasi ruangan ini terletak pada $6^{\circ} 10^{\prime} 43.8^{\prime \prime}$ lintang selatan dan $106^{\circ} 37^{\prime} 45.9^{\prime \prime}$ bujur timur.
Tujuan penelitian ini adalah mengidentifikasi besar beban pendinginan pengkondisi udara yang diperlukan pada bulan dimana nilai rata-rata beban pendinginan memiliki nilai terbesar dan terkecil, menentukan nilai maksimal, minimal dan rata-rata beban pendinginan dalam 1 tahun, dan merekomendasikan besar kepasitas sistem HVAC yang optimum.

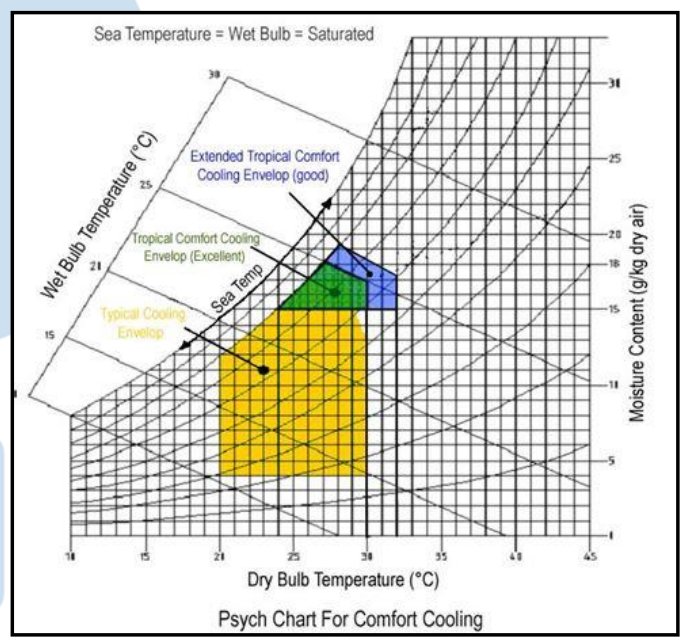

Gambar 1. Psychrometric Chart [2]

\section{LANDASAN TEORI}

A. Kenyamanan Termal

Kenyamanan termal tercapai jika 4 kondisi lingkungan berikut ini terpenuhi [3]:

- Suhu Udara

Suhu udara yang nyaman bagi kebanyakan (80\%) manusia adalah $20^{\circ} \mathrm{C}$ pada musim panas dan $25^{\circ} \mathrm{C}$ pada musim dingin.

- Kelembaban Relatif

Kelembaban relatif udara yang nyaman bagi kebanyakan $(80 \%)$ manusia adalah $20 \%-60 \%$ di musim panas dan 20\%-80\% di musim dingin. 
- Gerakan Udara

Rentang kenyamanan kecepatan angin bagi kebanyakan (80\%) manusia adalah dari 0,1 sampai $0,3 \mathrm{~m} / \mathrm{s}$.

\section{- Mean Radiant Temperature (MRT)}

MRT adalah suhu radiasi rata-rata, biasanya disebabkan oleh radiasi sinar matahari. Secara umum mRT harus di jaga agar mendekatri suhu udara lingkungan.

Kombinasi tertentu dari suhu udara, kelembaban relatif (RH), gerakan udara, dan MRT akan menghasilkan kenyamanan termal. Pada sebuah Psychometric Chart, MRT diasumsikan mendekati suhu udara dan gerakan udara diasumsikan rendah. Rentang kombinasi dari suhu udara dan RH yang nyaman ditunjukkan oleh Psychrometric Chart di Gambar 1.

\section{B. Perhitungan beban pendinginan}

Beban pendinginan dihasilkan dari proses perpindahan panas secara konduksi, konveksi, dan radiasi melalui selubung bangunan, sumber internal dan komponen sistem. Komponen bangunan yang dapat memengaruhi beban pendinginan meliputi [4]:

- Ekternal: dinding, atap, jendela, skylight, pintu, partisi, ceiling dan lantai

- Internal: lampu, penghuni, perlengkapan dan peralatan

- Infiltrasi: kebocoran udara, dan perpindahan kelembaban

- Sistem: Udara luar ruangan, duct leakage, reheat, fan dan pump energy, dan energy recovery

Variabel yang memengaruhi perhitungan beban pendinginan sangat banyak dan saling terkait. Komponen beban pendinginan bervariasi dalam nilai, arah dan selama periode 24 jam. Karena perubahan dalam komponen ini tidak seragam maka komponen harus dianalisis untuk menetapkan beban pendinginan dari suatu bangunan atau zona. Ada berbagai macam metode perhitungan beban pendinginan antara lain [4] [5] Transfer Function Method (TFM), Total Equivalent Temperature Differential (TETD), Heat Balance (HB), Radiant Time Series (RTS), Cooling load Temperature Difference (CLTD) / Solar Cooling Load (SCL) / Cooling Load Factor (CLF).

Acharya, Yewale, Tendolkar, dan Kulkarni mengestimasi dan menganalisis beban pendinginan untuk Subkontinen India. Dari studi ini, dapat disimpulkan bahwa metode TETD lebih cepat tetapi menghasilkan prediksi yang kurang akurat, sedangkan metode CLTD menghabiskan lebih banyak waktu dengan hasil yang akurat [6].
Adref, Elokda, Chikhalsouk, Alebri dan Alhosani [7] menggunakan metode CLTD/SCL/CLF untuk mengukur bangunan residensil di Abu Dhabi, Dubai. Hasil dari penelitian ini mengungkapkan bahwa puncak beban pendinginan sebesar $52 \mathrm{~kW}$ yang terjadi pada pukul 16 .

Sen, Rana, dan Punia [8] melakukan perbandingan estimasi beban pendinginan dengan menggunakan metode CLTD dan software komputer. Software komputer yang digunakan adalah Elite CHVAC. Hasilnya menunjukkan bahwa ketika nilai beban pendinginan yang didapatkan dengan metode CLTD cukup mendekati hasil dari Elite CHVAC.

Ijaola, Bello, dan Babalola [9] mengevaluasi performansi energi bangunan pada bangunan kantor yang kompleks di Nigeria. Hasilnya menunjukkan bahwa ketika nilai beban pendinginan yang didapatkan dengan metode CLTD cukup mendekati hasil dari SAVISCAD.

Antima dan Namrata [10] membandingkan 3 metode yaitu CLTD/Glass Load Factor (GLF), CLTD/CLF/SCL dan Residential Load Factor (RLF). Dari studi perbandingan ketiga metode di atas, dapat diketahui bahwa metode CLTD/GLF memprediksi perolehan panas pada sisi terendah sedangkan nilai metode CLTD/SCL/CLF mengarah pada nilai tertinggi dan nilai RLF berada diantara kedua metode dan lebih mendekati nilai metode CLTD/SCL/CLF.

\section{Metode Cooling load Temperature Difference (CLTD)[5]}

Pada penelitian ini digunakan metode Cooling Load Temperature Differnce (CLTD) untuk menghitung beban pendinginan bangunan. Perhitungan menggunakan CLTD, Solar Cooling Load (SCL), dan Cooling Load Factor (CLF) menggunakan prosedur umum yang relatif sama dengan Transfer Function Method (TFM) seperti penyatuan data. Demikian pula, konsep dasar perhitungan heat gain dari radiasi matahari, total heat gain melalui atap dan dinding luar, heat gain melalui permukaan interior, heat gain melalui infiltrasi dan ventilasi ditangani dengan cara yang sama. Metode CLTD/SCL/CLF adalah prosedur satu tahap perhitungan manual berdasarkan TFM. Ini digunakan untuk memperkirakan beban pendinginan pada 3 cara yaitu heat gain (konduksi melalui permukaan seperti jendela, atap, dan dinding, perolehan panas matahari melalui fenetrasi), dan heat gain dari lampu, penghuni, dan peralatan serta beban pendinginan dari infiltrasi dan ventilasi.

Persamaan beban pendinginan melalui atap, dinding, pintu dan konduksi kaca dinyatakan pada persamaan (1), (2), dan (3). Persamaan beban pendinginan melalui kaca secara radiasi matahari dinyatakan pada persamaan (4). Persamaan beban 
pendinginan melalui partisi, ceiling dan lantai dinyatakan pada persamaan (5). Persamaan beban pendinginan melalui pengguna ruangan dinyatakan pada persamaan (6) dan (7). Persamaan beban pendinginan melalui lampu dan peralatan dinyatakan pada persamaan (8) dan (9). Perolehan panas melalui ventilasi dan infiltrasi udara dinyatakan pada persamaan (10), (11), dan (12).

$$
\begin{gathered}
\mathrm{Q}=\mathrm{UxAxCLTDc} \\
\text { CLTDc = CLTD+(78-TR })+(\mathrm{TM}-85) \\
\mathrm{TM}=\mathrm{Tmax}-(\text { Daily range }) / 2 \\
\mathrm{Q}=\mathrm{AxSCxSCL} \\
\mathrm{Q}=\mathrm{UxAx}(\mathrm{Ta}-\mathrm{Trc}) \\
\mathrm{q}_{\text {sensible }}=\mathrm{Nx}(\mathrm{SHG}) \mathrm{XCLF} \\
\mathrm{q}_{\text {latent }}=\mathrm{Nx}(\mathrm{LHG}) \\
\mathrm{Q}=\mathrm{W} \times F_{\mathrm{UI}} \times F_{\mathrm{SA} C \mathrm{CLF}} \\
\mathrm{Q}=\mathrm{q}_{\text {input }} \times \mathrm{F}_{\mathrm{U}} \times \mathrm{F}_{\mathrm{L}} \times \mathrm{CLF} \\
\mathrm{q}_{\text {sensible }}=1,23 * \mathrm{Q}^{\prime} *\left(\mathrm{t}_{\mathrm{o}}-\mathrm{t}_{\mathrm{i}}\right) \\
\mathrm{q}_{\text {latent }}=3010 * \mathrm{Q} *\left(\mathrm{~W}_{\mathrm{o}}-\mathrm{W}_{\mathrm{i}}\right) \\
\mathrm{q}_{\text {total }}=1,2\left(\mathrm{~h}_{\mathrm{o}}-\mathrm{h}_{\mathrm{i}}\right)
\end{gathered}
$$

dengan,

$\mathrm{Q}=$ Cooling Load

$\mathrm{U}=$ Koefisien perpindahan panas $(U$-Value $)$

$\mathrm{A}=$ Luas permukaan

78-TR $=$ Koreksi desain suhu dalam ruangan

TM-85 = Koreksi desain suhu luar ruangan

$\mathrm{TR}=$ Suhu dalam ruangan

$\mathrm{TM}=$ Rata-rata suhu luar ruangan

Tmax = Suhu maximum luar ruangan

Daily Range = perbedaan suhu rata-rata antara maksimum dan minimum suhu harian

$\mathrm{SC}=$ Shading Coefficient

SCL $=$ Solar Cooling Load Factor

$\mathrm{Ta}=$ Suhu luar ruangan

$\operatorname{Trc}=$ desain suhu dalam ruangan yang dikondisikan

$\mathrm{N}=$ Jumlah penghuni dalam ruang

CLF = Cooling Load Factor

$\mathrm{SHG}=$ Sensible Heat Gain

LHG = Latent Heat Gain

$\mathrm{W}=$ Daya Lampu

$\mathrm{F}_{\mathrm{UI}}=$ Lighting use factor

$\mathrm{F}_{\mathrm{SA}}=$ Special balast allowance factor

$\mathrm{q}_{\text {input }}=$ Laju energi untuk penggunaan alat

$\mathrm{F}_{\mathrm{U}}=$ Usage Factor

$\mathrm{F}_{\mathrm{L}}=$ Radiation Factor

$Q^{\prime}=$ aliran udara pada ventilasi

$\mathrm{t}_{\mathrm{o}}, \mathrm{t}_{\mathrm{i}}=$ suhu udara luar, dalam ruangan

$\mathrm{W}_{\mathrm{o}}, \mathrm{W}_{\mathrm{i}}=$ ratio kelembaban luar, dalam ruangan

$\mathrm{h}_{\mathrm{o}}, \mathrm{h}_{\mathrm{i}}=$ entalpi luar, dalam ruangan

\section{Pengumpulan Dan Pengolahan Data}

A. Spesifikasi Bangunan dan Penggunaannya

Vihara Padumuttara adalah Vihara yang beralamat di Jl. Bakti No.14, RT.001/RW.004, Sukasari, Kec. Tangerang, Kota Tangerang, Banten. Dalam kordinat geografis Vihara Padumuttara terletak pada 6¹0'43.8” Lintang Selatan dan 106³7'45.9” Bujur Timur. Sketsa ruang Dhammasala ditunjukkan oleh Gambar 2 dan Gambar 3.

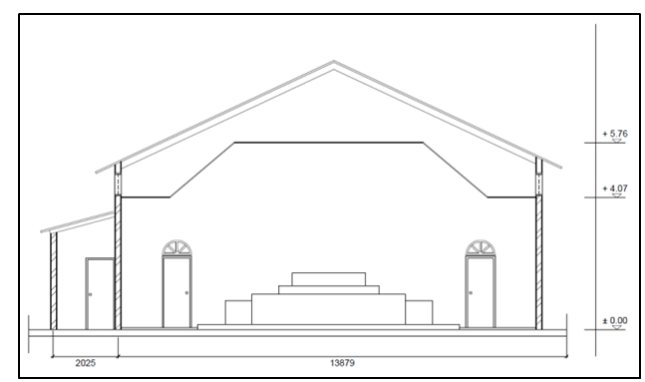

Gambar 2. Skesta Ruang Dhammasala Vihara Padumuttara Tampak Depan

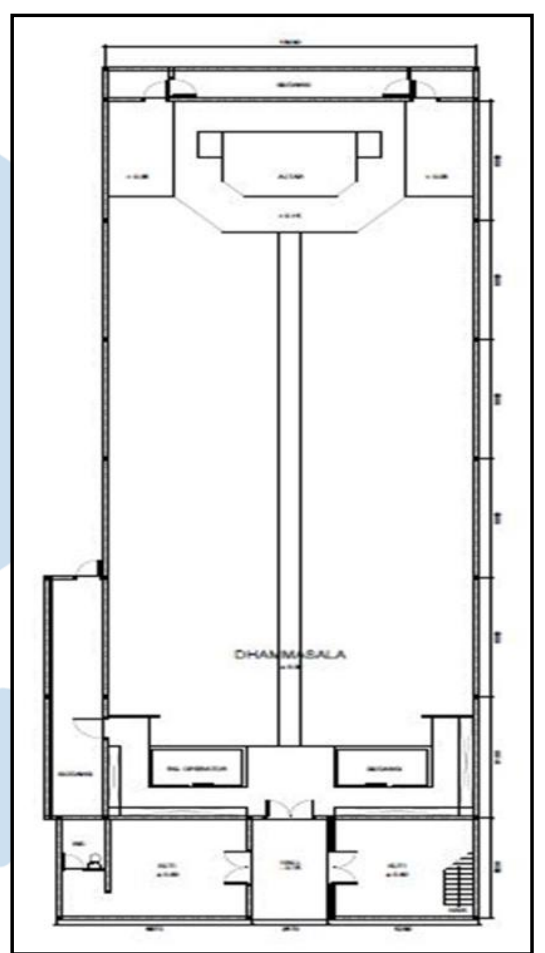

Gambar 3. Skesta Ruang Dhammasala Vihara Padumuttara Tampak Atas

Material bahan konstruksi dan luas komponen ruangan didapatkan penulis dari pengukuran dan spesifikasi dari pihak Vihara Padumuttara. Tabel 1 Menunjukkan konstruksi atap, dinding, kaca, ceiling, dan lantai ruangan. Selain jenis material dan luasnya, orientasi masing-masing komponen ruangan juga ditunjukkan.

Tabel 1. Konstruksi Ruang Dhammasala Vihara Padumuttara

\begin{tabular}{|l|l|l|}
\hline Komponen & \multicolumn{1}{|c|}{ Material } & \multicolumn{1}{c|}{ Luas $\left(\mathbf{m}^{\mathbf{2}}\right)$} \\
\hline Atap & $\begin{array}{l}\text { Zincalume, } \\
\text { Reflective } \\
\text { Aluminium }\end{array}$ & 558,72 \\
\hline Dinding & Common Brick, & 4 (Utara) dan \\
\hline
\end{tabular}




\begin{tabular}{|c|c|c|}
\hline Komponen & Material & Luas $\left(\mathbf{m}^{2}\right)$ \\
\hline & Cement Plaster & 4 (Selatan) \\
\hline Kaca & $\begin{array}{l}\text { Single Glazing } \\
3,2 \text { mm, fixed and } \\
\text { vertical insullation, } \\
\text { window frame } \\
\text { aluminium without } \\
\text { thermal break }\end{array}$ & $\begin{array}{l}\text { 50,88 (Timur) } \\
\text { dan 50,88 } \\
\text { (Barat) }\end{array}$ \\
\hline Pintu & $\begin{array}{l}\text { Wood door in wood } \\
\text { frame, no glazing }\end{array}$ & $\begin{array}{l}52 \text { (Utara dan } \\
\text { Selatan) dan } \\
95,84 \text { (Utara } \\
\text { dan Selatan) } \\
\end{array}$ \\
\hline Ceiling & Plywood 3,2mm & 489,6 \\
\hline Lantai & $\begin{array}{l}\text { Cement Plaster } \\
\text { cover with Vinyl }\end{array}$ & 288 \\
\hline
\end{tabular}

Jadwal pemakaian ruangan dan daftar peralatan elektronik yang dipakai selama kegiatan juga didapatkan penulis dari pengamatan dan informasi dari pihak Vihara. Tabel 2 menunjukkan jenis kebaktian dan waktu pelaksanaannya di ruangan. Tabel 3 menunjukkan total internal heat gain ruangan saat terpakai. Pada tabel tersebut, selain jumlah LCD proyektor, laptop, lampu flourescent, dan lampu LED yang nilainya tetap, juga ditunjukkan heat gain dari pengguna yang jumlahnya merupakan salah satu variabel bebas penelitian ini.

Tabel 2. Jadwal Penggunaan Ruang Dhammasala Vihara Padumuttara

\begin{tabular}{|l|l|l|}
\hline Kebaktian & Hari & Jam \\
\hline Meditasi & Senin & $19.30-21.30$ \\
\hline Orang Tua & Selasa & $19.00-21.00$ \\
\hline Liam Keng & Rabu & $19.00-21.00$ \\
\hline Muda Mudi & Kamis & $19.00-21.00$ \\
\hline Abhidhamma & Jumat & $19.30-21.30$ \\
\hline Remaja & Sabtu & $18.30-20.30$ \\
\hline Anak-anak & Minggu & $09.00-11.00$ \\
\hline Umum & Minggu & $19.00-21.00$ \\
\hline
\end{tabular}

Tabel 3. Total Internal Heat Gain

\begin{tabular}{|c|c|c|c|}
\hline Kategori & Jumlah & Total Heat Gain (W) \\
\hline Pengguna & 100 & 7630 \\
\hline & 200 & 15260 \\
\hline & 300 & 22890 \\
\hline LCD Proyektor & 1 & 104.43 \\
\hline Laptop & 1 & 12,98 \\
\hline Lampu Flourescent & 22 & 704,88 \\
\hline Lampu LED & 24 & \multicolumn{2}{|c|}{64.08} \\
\hline Total Internal Heat Gain (W) setiap variasi pengguna \\
\hline Pengguna & 100 & 200 & 300 \\
\hline Heat Gain (W) & 8516 & 16146 & 23776 \\
\hline
\end{tabular}

Pengukuran dalam ruangan oleh penulis dengan menggunakan Multi-Function Environment Meter Model 8820 menunjukkan bahwa ruangan pada keadaan kosong memiliki suhu sebesar $28,56^{\circ} \mathrm{C}$ dan relative humidity $(\mathrm{RH})$ sebesar $80,6 \%$. Berdasarkan psychrometric chart di Gambar 1, kondisi tersebut berasa diluar zona kenyamanan termal iklim tropis. Hal ini dapat dilihat juga pada SNI 03-6572-2001[11]. Mempertimbangkan RH yang telah diukur agar kenyamanan termal tercapai, temperatur ruangan harus berada pada rentang $24-27^{\circ} \mathrm{C}$ [2]. Dalam penelitian ini penulis menghitung beban pendinginan yang diperlukan untuk mencapai hal tersebut.

\section{B. Penyesuaian Persamaan}

Persamaan yang digunakan disesuaikan dengan keadaan di lokasi penelitian. Persamaan beban pendinginan pada lampu dan peralatan menggunakan persamaan yang diadaptasi, hal ini dilakukan karena nilai daya sudah diukur menggunakan Volt Craft Energy Check. Dengan kata lain nilai daya pada pengukuran sudah termasuk Usage factor, Radiation Factor, Lighting use factor, dan Special ballast allowance factor. Sehingga persamaannya sebagai berikut:

$$
\mathrm{Q}=\mathrm{W} \times \mathrm{NxCLF}
$$

Dimana,

$\mathrm{W}=$ daya peralatan

$\mathrm{N}=$ Jumlah peralatan

CLF $=$ Cooling Load Factor

\section{Variabel-varibel Penelitian}

Mempertimbangkan jadwal pemakaian pada Tabel 1, beban pendinginan yang dihitung pada studi ini adalah beban pendinginan pada pukul 20.00 (ketika ruangan dipakai). Perlu dicatat bahwa yang dihitung di sini adalah beban pendinginan puncak pada pukul 20.00, bukan beban pendinginan yang berubah-ubah dengan waktu. Variabel dependen dalam penelitian ini adalah beban pendinginan sedangkan variabel independen adalah suhu luar ruangan, suhu yang ingin dicapai dalam ruangan dan jumlah pengguna. Suhu luar ruangan (suhu atmosfer) berubah-ubah dengan hari dalam 1 tahun. Perubahan tersebut diperhitungkan dengan menggunakan data dari meteonorm [12]. Mempertimbangkan syarat kenyamanan termal, shu yang ingin dicapai dalam ruangan divariasikan $25^{\circ} \mathrm{C}, 24,5^{\circ} \mathrm{C}$, atau $24^{\circ} \mathrm{C}$. Adapun jumlah pengguna ruangan divariasikan sejumlah 100, 200, atau 300 orang. Jumlah tersebut merupakan jumlah tipikal pengguna saat ruangan terisi sedikit, sedang, atau penuh.

Pada penelitian ini juga ada variabel kontrol yang mempengaruhi beban pendinginan tetapi nilainya ditentukan oleh spesifikasi bangunan dan penggunaannya dan tidak berubah-ubah. Tabel 4 menunjukkan variabel-variabel kontrol dalam penelitian ini. Nilai masing-masing variabel tersebut didapatkan dengan mengolah data spesifikasi bangunan dan penggunaannya berdasarkan referensi yang tertera. 
Tabel 4. Variabel kontrol beserta referensinya

\begin{tabular}{|c|c|}
\hline Variabel & Referensi \\
\hline $\begin{array}{l}\text { Sensible dan Latent } \\
\text { Heat Gain pengguna }\end{array}$ & $\begin{array}{l}\text { ASHRAE } 1997 \text { Chapter } \\
28 \text { Table } 3\end{array}$ \\
\hline $\begin{array}{l}\text { Cooling Load Factor } \\
\text { pengguna dan peralatan }\end{array}$ & $\begin{array}{l}\text { ASHRAE } 1997 \text { Chapter } \\
28 \text { Table } 37\end{array}$ \\
\hline Daya peralatan & Pengukuran \\
\hline Daya lampu & Spesifikasi merk \\
\hline $\begin{array}{l}\text { Cooling Load Factor } \\
\text { lampu }\end{array}$ & $\begin{array}{l}\text { ASHRAE } 1997 \text { Chapter } \\
28 \text { Table } 38\end{array}$ \\
\hline $\begin{array}{l}\text { Luas permukaan } \\
\text { ceiling, lantai, atap, } \\
\text { pintu, jendela, dinding }\end{array}$ & Pengukuran \\
\hline Suhu luar ceiling & Meteonorm [12] \\
\hline Suhu luar lantai (tanah) & $20^{\circ} \mathrm{C}[13]$ \\
\hline U-Value Ceiling & $\begin{array}{l}\text { ASHRAE } 1997 \text { Chapter } \\
24 \text { Table } 4\end{array}$ \\
\hline U-Value Vinyl & $\begin{array}{l}\text { ASHRAE } 1997 \text { Chapter } \\
24 \text { Table } 4\end{array}$ \\
\hline $\begin{array}{l}\text { U-Value semen plaster } \\
\text { (E1) }\end{array}$ & $\begin{array}{l}\text { ASHRAE } 1997 \text { Chapter } \\
28 \text { Table } 11\end{array}$ \\
\hline $\begin{array}{l}\text { U-Value kaca pada } \\
\text { jendela }\end{array}$ & $\begin{array}{l}\text { ASHRAE } 1997 \text { Chapter } \\
29 \text { Table } 5\end{array}$ \\
\hline Shading Coefficient & $\begin{array}{l}\text { ASHRAE } 1997 \text { Chapter } 29 \\
\text { Table } 11\end{array}$ \\
\hline Solar Cooling Load & $\begin{array}{l}\text { ASHRAE } 1997 \text { Chapter } \\
28 \text { Table } 36\end{array}$ \\
\hline $\begin{array}{l}\text { CLTD jendela, pintu, } \\
\text { dinding }\end{array}$ & $\begin{array}{l}\text { ASHRAE } 1997 \text { Chapter } \\
28 \text { Table } 32\end{array}$ \\
\hline CLTD atap & $\begin{array}{l}\text { ASHRAE } 1997 \text { Chapter } \\
28 \text { Table } 30\end{array}$ \\
\hline U-Value pintu & $\begin{array}{l}\text { ASHRAE } 1997 \text { Chapter } \\
29 \text { Table } 7\end{array}$ \\
\hline U-Value dinding & $\begin{array}{l}\text { ASHRAE } 1997 \text { Chapter } \\
28 \text { Table } 11\end{array}$ \\
\hline U-Value atap & $\begin{array}{l}\text { ASHRAE } 2017 \text { Chapter } \\
33 \text { Table } 3 \text { \& ASHRAE } \\
1997 \text { Chapter } 24 \text { Table } 4\end{array}$ \\
\hline Jangkauan suhu harian & Meteonorm [12] \\
\hline
\end{tabular}

Dengan menggunakan data spesifikasi bangunan dan penggunaannya yang sudah diolah menjadi variabel-variabel kontrol, penulis menghitung nilai variabel dependen untuk masing-masing kombinasi variabel independen dengan menggunakan metode CLTD. Untuk membantu perhitungan dan visualisasi hasilnya, penulis menggunakan perangkat lunak spreadsheet (Microsoft Excel).

\section{HASIL PERHITUNGAN}

\section{A. Beban Pendinginan Hasil CLTD}

Beban pendinginan ruang Dhammasala Vihara Padumuttara terdiri dari 2 bagian yaitu internal heat gain dan eksternal heat gain. Perlu diingat bahwa menggunakan metode CLTD berarti nilai heat gain sama dengan cooling load artinya heat gain yang diterima komponen ruangan memiliki nilai yang sama dengan beban pendinginan (cooling load) yang diberikan. Hal ini memungkinkan karena metode CLTD sudah termasuk time delay dan time lag.

Internal heat gain terdiri dari heat gain yang dihasilkan pengguna, peralatan (LCD proyektor dan laptop), dan lampu. Untuk menghitungnya, pengguna ruangan diasumsikan duduk selama menggunakan ruangan sehingga nilai heat gain dari masing-masing pengguna adalah $70 \mathrm{~W}$ (sensible) dan $35 \mathrm{~W}$ (latent). Selain itu, jenis lampu yang digunakan pada ruangan ini adalah Flourescent dan LED masing masing berjumlah 22 dan 24 buah dengan daya $36 \mathrm{~W}$ dan $3 \mathrm{~W}$. Terakhir, berdasarkan pengukuran, besar daya LCD proyektor dan laptop masing-masing $177 \mathrm{~W}$ dan $22 \mathrm{~W}$. Berdasarkan nilai-nilai tersebut, nilai total internal heat gain untuk masing-masing jumlah pengguna ditunjukkan pada Tabel 3.

External heat gain adalah panas yang dihasilkan dari luar ruangan. Pada penelitian ini external heat gain meliputi ceiling, lantai, dinding, pintu, atap. Tabel 5 menunjukkan nilai variabel U-Value, CLTD, SCL dan SC pada setiap komponen ruangan. External heat gain dihitung pada bulan dengan nilai rata-rata cooling load tertinggi (Mei) dan terendah (Februari).

Tabel 5. Nilai variabel pada komponen ruangan

\begin{tabular}{|c|c|c|c|c|c|c|c|c|}
\hline \multirow[t]{2}{*}{ Komponen } & \multirow{2}{*}{$\begin{array}{c}\text { U-value } \\
\mathrm{W} /\left(\mathbf{m}^{2} .^{\circ} \mathrm{C}\right)\end{array}$} & \multicolumn{4}{|c|}{ CLTD $\left({ }^{\circ} \mathrm{C}\right)$} & \multicolumn{2}{|c|}{ SCL $\left({ }^{\circ} \mathrm{C}\right)$} & \multirow[t]{2}{*}{ SC } \\
\hline & & $\mathbf{U}$ & S & $\mathbf{T}$ & B & B & $\mathbf{T}$ & \\
\hline Atap & 1,75 & \multicolumn{4}{|c|}{14} & & & \\
\hline \begin{tabular}{|l} 
Dinding \\
\end{tabular} & 2,89 & 13 & 14 & 13 & 30 & & & \\
\hline Pintu & 2,61 & 13 & 14 & & & & & \\
\hline Kaca & 6,42 & & & 13 & 30 & 110 & 54 & 1 \\
\hline Ceiling & 35.71 & & & & & & & \\
\hline Lantai & 3,48 & & & & & & & \\
\hline
\end{tabular}

Nilai eksternal heat gain dan internal heat gain dijumlahkan dan hasilnya disajikan pada Gambar 4 untuk masing-masing jumlah pengguna (100, 200, atau 300). Gambar 5 menunjukkan beban pendinginan pada setiap hari selama 1 tahun. 


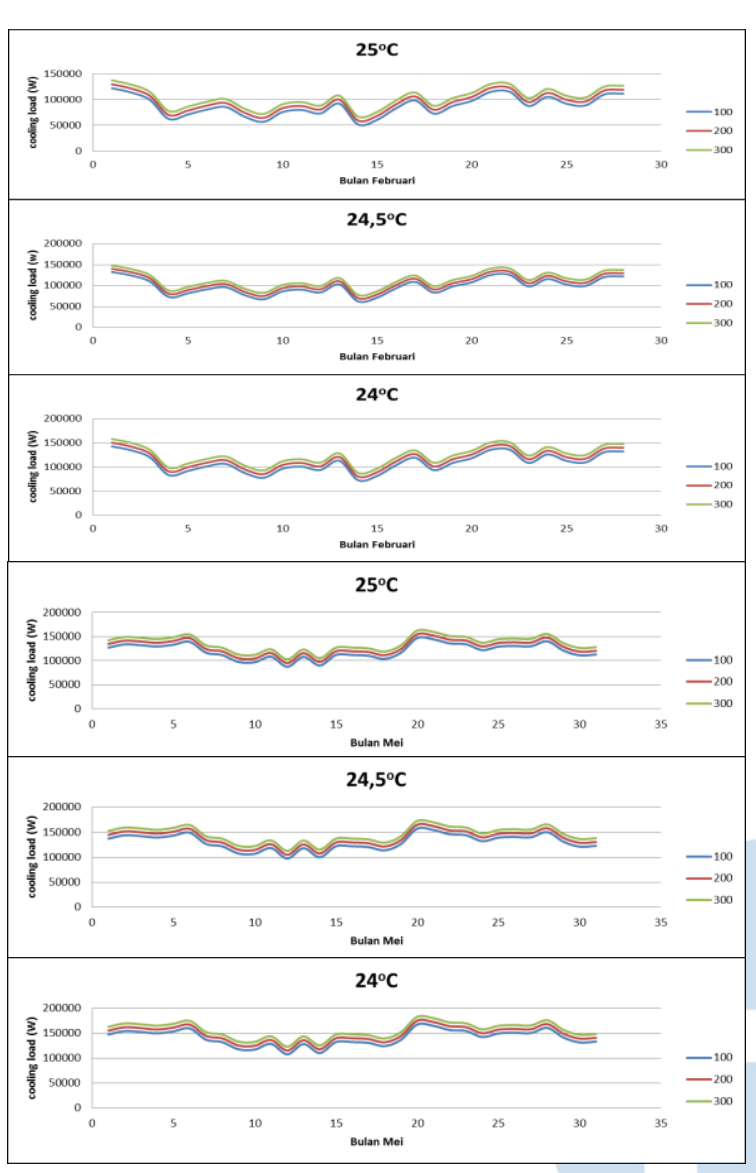

Gambar 4. Profil beban pendinginan pada bulan Februari dan Mei

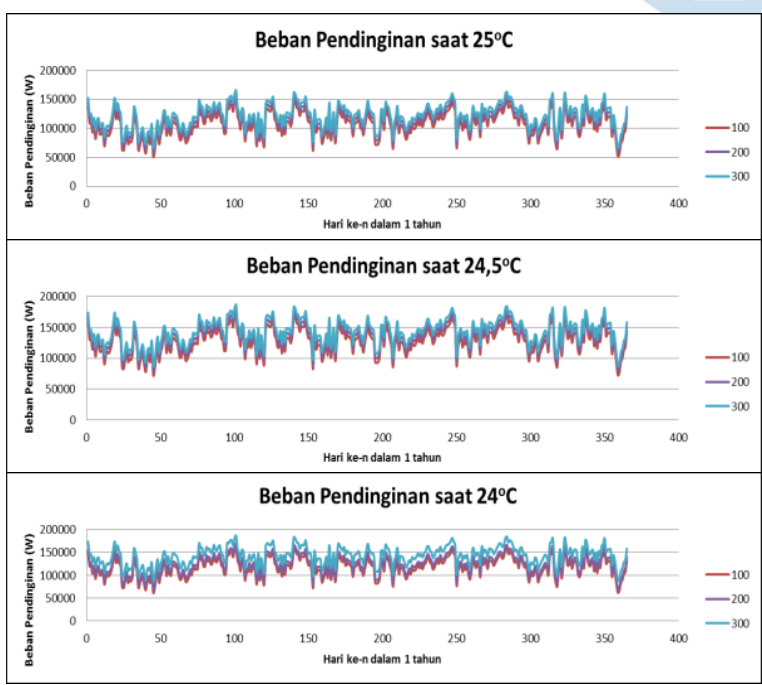

Gambar 5. Profil beban pendinginan harian selama 1 tahun

Pada Gambar 6 menunjukkan histogram frekuensi (jumlah hari) beban pendinginan (dalam satuan Ton Refrigerant (TR) ) pada masing-masing nilai suhu ruangan dalam satu tahun.

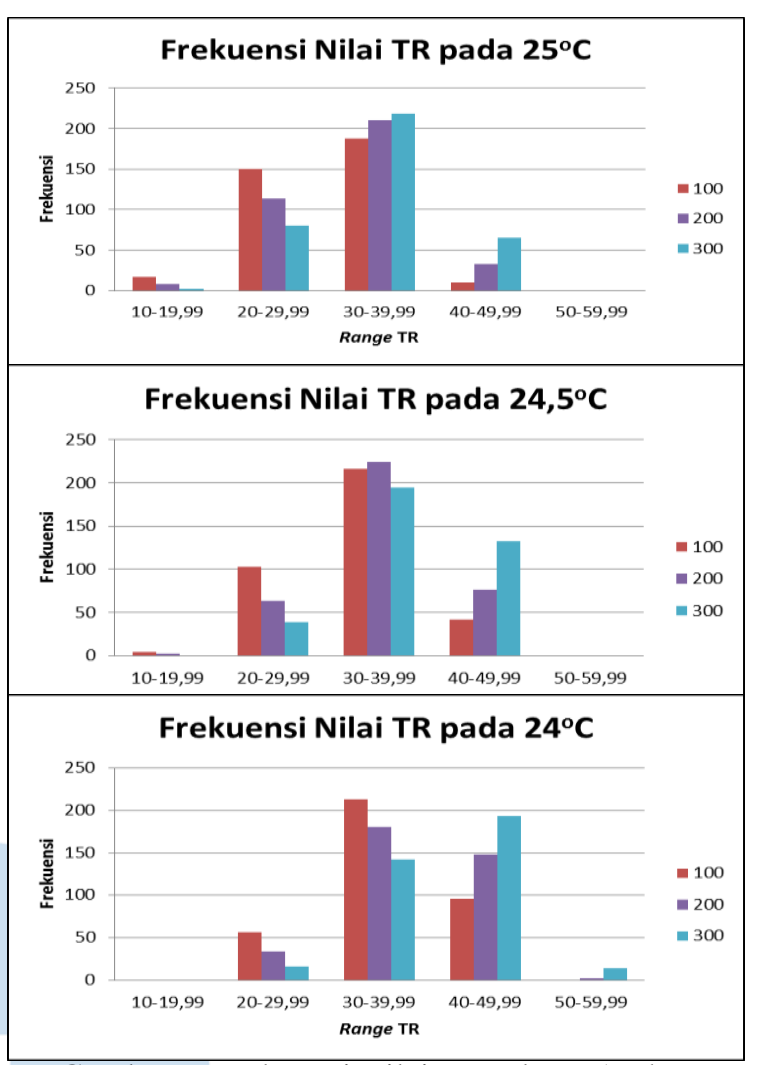

Gambar 6. Frekuensi Nilai TR selama 1 tahun

Ketiga grafik di atas menunjukkan bahwa nilai 3039,99TR $\approx 40 \mathrm{TR}$ memiliki frekuensi terbanyak disetiap perbedaan suhu desain dalam ruangan.

\section{B. Perbandingan Hasil}

Selanjutya hasil perhitungan penelitian ini dibandingkan dengan hasil perhitungan dari media perhitungan beban pendinginan lainnya. Media perhitungan beban pendinginan yang digunakan untuk perbandingan adalah HVAC Calculation, Cooling Load Calculator, Cleanair.co.uk, Daikin.com. Gambar 7 menunjukkan persentase perbedaan hasil ke-4 media perhitungan dengan perhitungan mengguakan CLTD dimana hasil perhitungan sudah mengalami penyesuaian dengan variabel input di setiap media perhitungan.

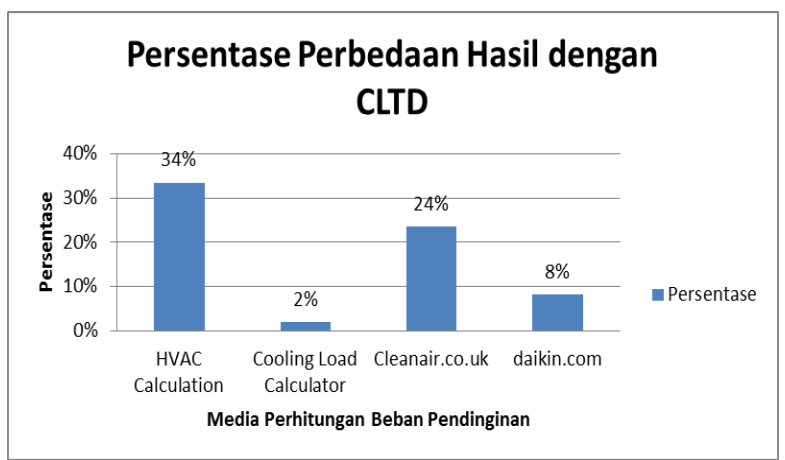

Gambar 7. Persentase Perbedaan Media

Perhitungan Beban Pendinginan dengan CLTD 
Perbedaan nilai persentase dipengaruhi oleh variabel yang dapat dimasukkan pada ke-4 media perhitungan dan penyesuaian pada metode CLTD. Hal ini dapat dilihat pada aplikasi HVAC Calculation dan Cleanair.co.uk. Variabel masukkan aplikasi ini sangat sedikit, sehingga mempengaruhi penyesuaian variabel dalam perhitungan CLTD. Walaupun sudah disesuaikan dengan variabel yang ada, hasilnya tetap jauh karena pemasukkan data yang terbatas di aplikasi tersebut. Selain itu variabel tetap di aplikasi tersebut memiliki kemungkinan berbeda dengan variabel di CLTD. Sebaliknya pada aplikasi Cooling Load Calculator dan Daikin.com, kedua aplikasi tersebut memiliki paling sedikit penyesuaian dari perhitungan CLTD. Hal ini terjadi karena data yang dimasukkan pada media perhitungan tersebut dapat disamakan dengan data di CLTD sehingga perbedaan persentasenya semakin sedikit.

\section{KESIMPULAN}

Berdasarkan hasil perhitungan beban pendinginan ruang Dhammasala Vihara Padumuttara dapat disimpulkan sebagai berikut:

1. Setiap penurunan $0,5^{\circ} \mathrm{C}$ pada suhu dalam ruangan, besar beban pendinginan akan bertambah sebesar $10 \mathrm{~W}$. Setiap penambahan jumlah pengguna 100 orang, beban pendinginan akan bertambah sebesar 7,6 $\mathrm{kW}$ dengan asumsi pengguna dalam kondisi duduk.

2. Beban pendinginan pada bulan Mei (bulan dengan nilai rata-rata beban pendinginan tertinggi) mengalami peningkatan sebesar 32 kW dibandingkan bulan Februari (bulan dengan nilai rata-rata beban pendinginan terendah). Tabel 6 menunjukkan beban pendinginan yang dibutuhkan pada bulan Februari dan Mei. Tabel 7 menunjukkan nilai maksimal, minimal dan rata-rata beban pendinginan dalam 1 tahun.

Tabel 6. Besar Beban Pendinginan Bulan Februari dan Mei

\begin{tabular}{|c|c|c|c|c|}
\hline \multicolumn{2}{|c|}{ Cooling Load $(\mathbf{k W})$} & $\mathbf{1 0 0}$ & $\mathbf{2 0 0}$ & $\mathbf{3 0 0}$ \\
\hline \multirow{3}{*}{ Februari } & $25^{\circ} \mathrm{C}$ & 87,7 & 95,3 & 103 \\
\cline { 2 - 5 } & $24,5^{\circ} \mathrm{C}$ & 98,2 & 105,8 & 113,4 \\
\cline { 2 - 5 } & $24^{\circ} \mathrm{C}$ & 108,7 & 116,3 & 123,9 \\
\hline \multirow{3}{*}{ Mei } & $25^{\circ} \mathrm{C}$ & 119,9 & 127,5 & 135,1 \\
\cline { 2 - 5 } & $24,5^{\circ} \mathrm{C}$ & 130,4 & 138 & 145,6 \\
\cline { 2 - 5 } & $24^{\circ} \mathrm{C}$ & 140,9 & 148,5 & 156,1 \\
\hline
\end{tabular}

Tabel 7. Nilai Maksimal, Minimal, dan Rata-Rata Beban Pendinginan dalam 1 Tahun

\begin{tabular}{|c|c|c|c|c|}
\hline \multicolumn{2}{|c|}{ Cooling Load (kW) } & $\mathbf{1 0 0}$ & $\mathbf{2 0 0}$ & $\mathbf{3 0 0}$ \\
\hline \multirow{2}{*}{$25^{\circ} \mathrm{C}$} & Max & 149,9 & 157,5 & 165,1 \\
\cline { 2 - 5 } & Min & 51,4 & 59 & 66,6 \\
\hline
\end{tabular}

\begin{tabular}{|c|c|c|c|c|}
\hline \multicolumn{2}{|c|}{ Cooling Load (kW) } & $\mathbf{1 0 0}$ & $\mathbf{2 0 0}$ & $\mathbf{3 0 0}$ \\
\hline & Mean & 106,3 & 113,9 & 121,5 \\
\hline \multirow{3}{*}{$24,5^{\circ} \mathrm{C}$} & Max & 160,4 & 168 & 175,6 \\
\cline { 2 - 5 } & Min & 61,9 & 69,5 & 77,1 \\
\cline { 2 - 5 } & Mean & 116,8 & 124,4 & 132 \\
\hline \multirow{3}{*}{$25^{\circ} \mathrm{C}$} & Max & 170,9 & 178,5 & 186,1 \\
\cline { 2 - 5 } & Min & 72,4 & 80 & 87,6 \\
\cline { 2 - 5 } & Mean & 127,3 & 134,9 & 142,5 \\
\hline
\end{tabular}

3. Rekomendasi sistem HVAC adalah pengkondisian udara Chiller dengan kapasitas 30 TR sampai dengan 39,99 TR $\approx 40 \mathrm{TR}$.

\section{UCAPAN TERIMA KASIH}

Penelitian ini tidak dapat diselesaikan jika tanpa adanya bantuan dari orang-orang sekitar. Untuk itu, penulis ingin mengucapkan terima kasih kepada;

1. Orang tua yang telah memberikan semangat dan doa kepada penulis dalam penyelesaian penelitian ini.

2. Bapak Caesar Ondolan Harahap, Ph.D dan Ibu Dr. Techn. Rahmi Andarini, S.T., M.Eng.Sc yang telah memberikan bimbingan dan saransaran yang diberikan kepada penulis selama pengerjaan penelitian.

\section{DAFTAR PUSTAKA}

[1] Lei, J., Yang, J., \& Yang, E.H., "Energy performance of building envelopes integrated with phase change materials for cooling load reduction in tropical Singapore," Applied Energy, no. 162, pp. 207-217, 2016.

[2] Puride, N., "Passive Design in the pacific environment," Newmarket, Auckland: Connell Wagner Limited, 2016.

[3] Lechner, N., "Heating, cooling, lighting: sustainable design methods for architects," Hoboken, NJ: John Wiley \& Sons, Inc, 2015.

[4] 2017 Ashrae handbook: Fundamentals, Atlanta, GA, 2017, pp. 18.1-18.60.

[5] 1997 Ashrae handbook: Fundamentals, Atlanta, GA, 1997, pp. 28.1-28.65.

[6] Acharya, K. G., Yewale, G. P., Tendolkar, M. V., \& Kulkarni, S. H., "Estimation and Analysis of Cooling Load for Indian Subcontinent by CLD/SCL/CLF method at part load conditions," In Journal of Physics: Conference Series., 2019, pp. 1-8.

[7] Adref, K., Elokda, Y., Chikhalsouk, M., Alebri, A., \& Alhosani, H., "Residential Peak Cooling Load and Peak Solar Time for Typical UAE Conditions," In 2019 Advances in Science and Engineering Technology International Conferences., 2019, pp. 1-5.

[8] Sen, U. K., Rana, R., \& Punia, A., "Comparison of Cooling Load Estimation by CLTD Method and Computer Software," IRJET, vol. 3, no. 7, pp 1378-1380, July. 2016.

[9] Ijaola, A. O., Bello, I. T., \& Babalola, J. B., "Building Energy Performance Evaluation for an Office Complex in Nigeria." IJSER, vol. 9, no. 5, pp 316-321, May. 2018.

[10] Sharma, A., \& Sengar, N., "Heat Gain Study of a Residential Building in Hot-Dry Climatic Zone on Basis of Three Cooling Load Methods.” EJERS, vol. 4, no. 9, pp 186-194. Sept 2019.

[11] SNI 03-6572-2001: Tata Cara perancangan sistem ventilasi dan pengkondisian udara pada bangunan gedung, Jakarta, DKI Jakarta, Indonesia, 2001, pp. 11.

[12] Meteonorm Handbook, Manual and Theoretical Background, Switzerland, 2009. 
[13] Wiguna, D., "Identifikasi Suhu Permukaan Tanah Dengan Metode Konversi Digital Number Menggunakan Teknik Penginderaan Jauh dan Sistem Informasi Geografi,” Jurnal
Teknologi Informasi dan Komunikasi, vol. 6, no. 2, pp 59-69, Dec. 2017. 